\title{
Lung Maturation in the Hyperinsulinemic Rat Fetus
}

\author{
BERNADETTE PIGNOL, JACQUES BOURBON, ALAIN KTORZA, LEA MARIN, \\ MICHEL RIEUTORT, AND CLAUDE TORDET \\ Laboratoire de Physiologie du Développement, Collège de France, [B.P., J.B., M.R.]; Laboratoire de Physiologie \\ du Développement, Lab. Assoc. CNRS 307, Université Paris VII [A.K.]; INSERM U29, Hôpital de Port Royal \\ [L.M., C.T.]; and UER 61, Université Pierre et Marie Curie [M.R.], Paris, France
}

\begin{abstract}
Hyperinsulinemic rat fetuses were obtained either by repeated in utero injections of long-acting insulin (resulting in fetal hypoglycemia) or by chronically infusing intravenous glucose to the mother (resulting in fetal hyperglycemia). Fetuses were examined at term. In insulininjected fetuses $(n=15)$, surfactant $(S)$ fraction phosphatidylcholine (PC) and disaturated phosphatidylcholine (DSPC) were significantly decreased $(3.6 \pm 0.1 \mathrm{nmol} P \mathrm{Pi} /$ $\mathrm{mg}$ tissue; $p<0.001$ and $2.8 \pm 0.1 \mathrm{nmol} / \mathrm{mg} ; p<0.025$, respectively) as compared with their saline-injected controls $(4.8 \pm 0.2$ and $3.3 \pm 0.1 \mathrm{nmol} / \mathrm{mg}$, respectively, $n=$ 19). However, residual (R) fraction was unchanged, and there was no difference in whole-lung phospholipids (combined $S$ and $R$ fractions). These results are consistent with morphological data showing a lower lamellar body area per type II cell profile in insulin-injected fetuses as compared with their controls [1.41 $\pm 0.13 \mu \mathrm{m}^{2}(n=72)$ versus $\left.1.99 \pm 0.14 \mu \mathrm{m}^{2}(n=129) p<0.01\right]$. Glycogen content was slightly higher in insulin-injected fetuses $(18.5 \pm 1.0$ $\mu \mathrm{g} / \mathrm{mg}, n=17)$ than in their controls $(15.1 \pm 0.8 \mu \mathrm{g} / \mathrm{mg}, n$ $=18 ; p<0.05)$. In the second model, changes in $\mathrm{S}$ fraction $\mathrm{PC}$ and DSPC were similar to those observed after insulininjections: $4.3 \pm 0.25$ and $3.4 \pm 0.2 \mathrm{nmol} \mathrm{Pi/mg} \mathrm{in} \mathrm{fetuses}$ of glucose-infused rats $(n=10)$ versus $5.7 \pm 0.45$ and 4.3 $\pm 0.3 \mathrm{nmol} \mathrm{Pi} / \mathrm{mg}$, respectively, in controls $(n=10, p<$ $0.05)$. In addition, $P G$ was also decreased $(0.24 \pm 0.03$ versus $0.40 \pm 0.04 \mathrm{nmol} \mathrm{Pi} / \mathrm{mg}, n=10 ; p<0.01$ ), and in contrast with insulin injections, reductions of DSPC and PG were detectable in whole lung. However, glycogen content was unchanged by glucose infusion $(13.7 \pm 1.0 \mu \mathrm{g} /$ $\mathrm{mg}, n=15$ versus $14.0 \pm 1.1 \mu \mathrm{g} / \mathrm{mg}, n=20$ in controls). In both models, the phospholipid composition of material recovered by lung lavage was unchanged. (Pediatr Res 21 : 436-441, 1987)
\end{abstract}

Abbreviations

$S$ fraction, surfactant fraction

$R$ fraction, residual fraction

TPL, total phospholipids

PC, phosphatidylcholine (total)

DSPC, disaturated phosphatidylcholine

PE, phosphatidylethanolamine

PI, phosphatidylinositol

PG, phosphatidylglycerol

IRI, immunoreactive insulin

$\left[{ }^{14} \mathrm{C}\right]-\mathrm{DPPC},\left[{ }^{14} \mathrm{C}\right]$-dipalmitoylphosphatidylcholine

Received July 17, 1986; accepted December 4, 1986.

Correspondence and reprint requests Dr. Jacques Bourbon, Laboratoire de Physiologie du Developpement, College de France, 11 Place Marcelin Berthelot, F 75231 Paris, Cedex 05, France.

Supported by INSERM Grant PRC-135002 "Reproduction et Développement."
The incidence of respiratory distress syndrome is increased in infants of diabetic mothers (1). This appears to result from a delayed maturation of the pulmonary surfactant system (2).

A prominent feature of the fetus of diabetic mother is the association of hyperglycemia and reactional hyperinsulinemia (3). In vitro, an excess of insulin has been repeatedly shown to delay fetal lung maturation (reviewed in Ref. 2). In vivo, however, the implication of hyperinsulinism in the mechanisms delaying lung maturation remains up to now an unsolved question. The maturational response of fetal lamb lungs to cortisol (4) was inhibited by chronic hyperglycemia and secondary hyperinsulinemia. Inducing hyperinsulinemia by litter-size reduction decreased amniotic fluid surfactant in fetal rabbits (5). By contrast, inducing primary hyperinsulinemia in fetal rabbit or monkey in utero (6-8) failed to delay lung maturation. Furthermore, delayed lung maturation was observed in $\beta$-cytotoxic agent-induced animal models of diabetic pregnancy in which fetuses were devoid of reactional hyperinsulinism (9-13). Both the latter approaches suggest that the delay in lung maturation could be a direct consequence of chronic hyperglycemia, not involving hyperinsulinemia.

In the present study, the problem was reinvestigated with aid of two experimental approaches: 1) sustained hyperinsulinemia achieved by repeated insulin injections in utero and 2) chronic intravenous infusion of glucose to the mother (14), resulting in fetal hyperglycemia and secondary hyperinsulinemia. Fetal lung maturity near term was estimated by analyzing phospholipid composition of a subcellular surfactant fraction isolated from tissue and of fluid collected by bronchoalveolar lavage. Quantitative examination of type II pneumocytes by transmission electron microscopy was performed in insulin-injected fetuses and their controls.

\section{MATERIALS AND METHODS}

Animal models and collection of samples. Wistar rats weighing approximately $250 \mathrm{~g}$ were used. Gestation was dated from the time of fecondation presumably occurring at $0100 \mathrm{~h}$ the night of mating. The day following mating was designated day 0 of gestation. Term is 22 days. The mean litter size was about 10 .

Long-acting insulin (Novo-Industry, Copenhagen, Denmark) was given subcutaneously to the fetuses through the uterine wall and fetal membranes, under maternal ether-anesthesia. Fetuses received $0.1 \mathrm{U}$ of insulin $(2.5 \mu \mathrm{l})$ on day 18.5 , then $0.2 \mathrm{U}(5 \mu \mathrm{l})$ on days 19.5 and 20.5 of gestation, at $1000 \mathrm{~h}$. Control fetuses received the same volume of saline. Insulin and saline were injected in separate litters. Three fetuses were injected in each uterine horn, randomization being obtained by injecting one fetus in the upper part, one fetus in the median part, and one fetus in the lower part of the horn. Collection of fetal samples was done at 21.5 days gestational age. A few litters were studied morphologically on day 20.5 after two injections. 
Glucose $(30 \%$ glucose sterile solution, Chaix and Dumarais, Paris, France, $1.8 \mathrm{ml} / \mathrm{h}$ ) was infused in unrestrained pregnant rats from gestational day 15 to term, through a catheter chronically inserted in jugular vein (14). Control rats received an equivalent amount of distilled water. Distilled water was used to avoid sodium overload; due to the low flow rate in the superior vena cava, hemolysis was not observed (14). Maternal glycemia was measured daily on blood samples taken at the cut tip of the tail, using a semiquantitative method (Haemoglukotest, Boehringer, Mannheim, FRG). Collection of fetuses was done on day 21.5.

The fetuses were collected under maternal ketamine chlorhydrate anesthesia. Fetuses were taken successively. Blood sampling was performed after incision of axillary vessels with the placenta kept in situ. Then the fetal lungs were removed and in some instances a small portion of median lobe of right lung was fixed for electron microscopy and the rest was immediately frozen in liquid nitrogen. Lungs were stored at $-25^{\circ} \mathrm{C}$ until biochemical determinations.

Newborn lung lavages were performed as previously described (15) on different litters. In brief, rats were killed by a blow to the head and their fetuses were delivered by cesarean section. They were allowed to breathe for $30 \mathrm{~min}$ at $26-28^{\circ} \mathrm{C}$. After decerebration, a cannula was inserted in the trachea and the lungs lavaged six times with saline to total lung capacity. As previously reported (15), six lavages were optimal for recovery of material and approximately $90 \%$ of instilled volume was recovered. Phospholipid composition was determined on the pooled lavage fluids from five to seven newborns of a same litter.

Preparation of surfactant fraction. Surfactant fraction was isolated from frozen lungs by discontinuous sucrose gradient ultracentrifugations according to the method of Frosolono et al. (16) as revised by Sanders and Longmore (17) and adapted to small size samples (18). In brief, lung tissue was homogenized in isotonic Tris-HCl-EDTA-saline buffer, $\mathrm{pH} 7.4$ and layered on buffer containing $0.75 \mathrm{~mol} /$ liter sucrose. The crude surfactant fraction was recovered at the interphase after centrifugation for $1 \mathrm{~h}$ at $45,000 \times g$. After dilution in buffer, it was layered on a discontinuous gradient of sucrose 0.25 and $0.68 \mathrm{~mol} / \mathrm{liter}$. Purified $\mathrm{S}$ fraction was recovered at the interphase of gradient after centrifugation for $1 \mathrm{~h}$ at $64,000 \times g$. Combined upper and lower phases of both centrifugations constituted the residual (nonsurfactant) fraction. To avoid pitfalls due to possible variations in recovery, a trace amount of previously prepared labeled surfactant fraction was added to the tissue at the time of homogenization. The labeled $S$ fraction was made by injecting a 20.5 day pregnant rat with $100 \mu \mathrm{Ci}$ of $\left[{ }^{3} \mathrm{H}\right]$-methylcholinechloride $(85 \mathrm{Ci} /$ nmol, CEA, Bures, France) via the saphenous vein. Twenty-four $\mathrm{h}$ later, the rat was sacrificed and fetal lungs removed and pooled for isolation of the surfactant fraction. Phospholipid composition of the surfactant fraction and radioactivity incorporated into phospholipids were determined as stated below. $\left[{ }^{14} \mathrm{C}\right]-\mathrm{DPPC}$ (CEA) was added in trace amount to determine recovery after processing for phospholipid determination, and aliquot samples of phospholipids were counted to determine ${ }^{3} \mathrm{H}$ and ${ }^{14} \mathrm{C}$ activities. About 90 and $75 \%$ of radioactivity were found in PC and DSPC, respectively. About $2500 \mathrm{dpm}{ }^{3} \mathrm{H}$ representing $25 \mathrm{nmol} \mathrm{Pi}$ (total phospholipids) were added to each sample before $\mathrm{S}$ fraction extraction to allow loss estimates both during extraction and phospholipid determination. For residual fraction, recovery was determined as described above by adding $\left[{ }^{14} \mathrm{C}\right]-\mathrm{DPPC}$ to the sample before lipid extraction, according to previous work (19). Phospholipid content of whole lung was calculated by summing up $\mathrm{S}$ and $\mathrm{R}$ fractions.

Biochemical determinations. Blood glucose was determined by G.O.D. Perid method of Boehringer. Plasma immunoreactive insulin was determined by radioimmunoassay (20).

Glycogen content was determined as described by Chan and Exton (21) on distilled water homogenates of lung tissue. Protein concentrations was determined on the homogenates prepared for glycogen assay according to Schacterle and Pollack (22).
Phospholipids were extracted from $\mathrm{S}$ and $\mathrm{R}$ fractions or from lavage fluid by mixing them with $4 \times$ vol of chloroform:methanol $2: 1(\mathrm{v} / \mathrm{v})$, according to the procedure of Folch et al. (23) and shaking vigorously for $10 \mathrm{~min}$. Lipid extracts were recovered in chloroform phase and fractionated into individual components by thin layer chromatography on silica gel plates (Merck, Darmstadt, FRG). After elution from gel, phosphate assay was performed on mineralized phospholipids as described previously (19). Total phospholipids, total phosphatidylcholine, phosphatidylethanolamine, phosphatidylinositol, and phosphatidylglycerol were thus determined. Disaturated phosphatidylcholine was extracted from an aliquot fraction of the $\mathrm{PC}$ spot by the $\mathrm{OsO}_{4}$ method of Mason et al. (24).

Neutral lipids were separated by thin-layer chromatography using petroleum ether, diethyloxide, acetic acid $(75: 24: 1, \mathrm{v} / \mathrm{v})$ as developing solvent, from a lipid extract prepared from whole lung tissue homogenized in $20 \times$ vol of chloroform:methanol $2: 1(\mathrm{v} / \mathrm{v})(7)$. Glycerol content of di- and triglycerides was determined after saponification (25).

Electron microscopy. Lung tissue was fixed according to Hirsch and Fedorko (26), dehydrated in aceton, infiltrated, and embedded in Epon. Thin sections were stained with uranyl acetate and lead citrate and examined with a Hitashi electron microscope. Electron micrographs of type II pneumocytes were taken at random. Only sagittal or slightly parasagittal sections, i.e. sections passing through the basal and luminal sides of the cell and the nucleus were used for morphometric analysis at the final magnification of $\times 7500$ as described previously (15). According to Weibel et al. (27), on the bases of mathematical analyses, surface area of a given structure found in a section is proportional to the volume of this structure in a tridimensional system. Thus, the surface area of cell profiles and of the organelles they content is representative of their volume. Cell surface and lamellar body area were measured using a Kontron MOP 1 image analyzer. The extent of glycogen patches was estimated by point counting. Fetuses of at least three different litters were used for each group.

Statistical analysis. Means are accompanied with SEM throughout the study. Statistical comparison of means was made between experimental groups and their appropriate controls using the Student's $t$ test for unpaired values.

\section{RESULTS}

Fetal blood glucose and insulin. In order to determine the temporal changes induced in blood glucose and insulin concentrations by insulin injections, insulin was administered to 18.5-, 19.5- or 20.5-day-old fetuses, in litters distinct from those used for fetal lung studies. Glycemia and plasma IRI were determined $4,8,16$, or $24 \mathrm{~h}$ after the injection. Different rats were used for each time of the study. The results reported in Figure 1 show that although the peak of plasma insulin was extremely high a few hours after injection, insulin concentration had probably returned to an almost normal level at the time of the next injection. Therefore, although they may appear very high, the dosages which were administered were necessary to obtain a sustained hyperinsulinemic state in those fetuses which were given insulin three times. Hyperinsulinemia went along with marked and sustained hypoglycemia.

Blood glucose of rats chronically infused with glucose slightly fluctuated around a median value of $11 \mathrm{mmol} / \mathrm{liter}$. At term, the fetuses were hyperglycemic $(9.4 \pm 0.3 \mathrm{mmol} / \mathrm{liter}, n=19$ versus $2.6 \pm 0.2 \mathrm{mmol} /$ liter, $n=20$ in controls, $p<0.001$ ) and hyperinsulinemic (plasma IRI $=567 \pm 42 \mathrm{mU} /$ liter, $n=29$ versus $262 \pm 19 \mathrm{mU} /$ liter, $n=20$ in controls, $p<0.001$ ).

Fetal weight, lung weight, lung protein, and glycogen contents (Table 1). Fetal weight and lung weight were slightly larger in insulin-injected fetuses than in their saline-injected controls, which is in agreement with the results of a similar previous study (28). Fetuses from glucose-infused rats were slightly lighter than their controls but lung weight was not significantly different. Lung water content was not changed by the treatments; it was 
$87.0 \pm 0.4 \%$ in insulin-injected fetuses and $87.3 \pm 0.3 \%$ in fetuses of glucose-infused rats versus $88.0 \pm 0.4 \%$ and $87.7 \pm$ $0.4 \%$ in their respective controls ( $n=5$ in each group).

Lung proteins were unchanged by insulin injection or glucose infusion. Glycogen content was about $20 \%$ higher in insulininjected fetuses as compared with their controls. No significant difference was observed for glycogen content between fetuses of glucose-infused rats and their controls.

Lipid analyses of lung tissue. Surfactant fraction in salineinjected fetuses or in fetuses of water-infused rats was similar to that reported in undisturbed normal rat fetuses of the same age (29), although it appeared slightly increased. It is possible that

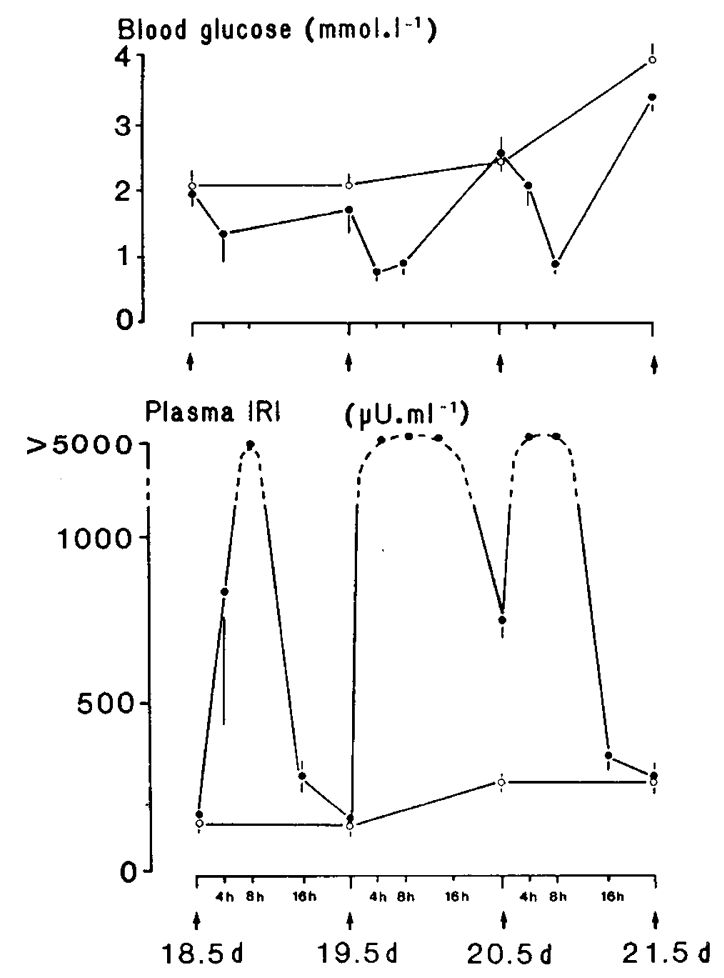

Fig. 1. Blood glucose and plasma immunoreactive insulin $(I R I)$ following insulin injection (arrows) in utero on day $18.5(0.1 \mathrm{U})$ or days 19.5 or $20.5(0.2 \mathrm{U})$. Two litters were used for each time of the study. Fetal blood was collected 4, 8, 16, or $24 \mathrm{~h}$ after the injection. Hyperinsulinemic state was sustained for long periods and went along with marked hypoglycemia. Closed circles, insulin-injected fetuses; open circles, normal evolution in controls. stress induced by the procedures somewhat stimulated fetal lung maturation.

Total phospholipids, PC, DSPC, and PE of S fraction were significantly lower in insulin-injected fetuses as compared with their controls. No significant change was observed for phospholipids of $R$ fraction. When combining $S$ and $R$ fractions for obtaining phospholipid composition of whole lung, no significant change was observed for any phospholipid. Neither diglyceride nor triglyceride content were modified by insulin injection (Table 2).

Total phospholipids, PC, DSPC, and PG were reduced in S fraction of fetuses from glucose-infused rats as compared with their controls. The reduction was about $20 \%$ for PC and DSPC and as much as $40 \%$ for PG. In R fraction, PC and PE were slightly increased and $P G$ decreased. When combining $S$ and $R$ fractions, only DSPC and PG remained significantly decreased; $P E$ was increased but the difference was small. Neither diglyceride nor triglyceride content were modified by glucose infusion (Table 3).

Lung lavage study (Table 4). Phospholipid composition of material recoverable by the standardized lung lavage procedure was not modified in insulin-injected newborns or in newborns from glucose-infused rats as compared with their appropriate controls.

Morphometry of type II pneumocytes. This study was performed in fetuses injected with insulin and in their saline-injected controls on gestational days 20.5 (two insulin injections) and 21.5 (three insulin injections). The mean surface area of type II cell sections was equal in the two series at both stages (Fig. 2). The average number of lamellar bodies per cell was unchanged, but the mean total lamellar body area per cell profile was significantly reduced at both stages in insulin-injected fetuses as compared with controls (Fig. 2). As far as this parameter is representative of total lamellar body volume per cell, it indicates a reduction of surfactant content per pneumocyte.

The area occupied by glycogen patches was the same in insulintreated fetuses and controls on day 20.5 (respectively $11.7 \pm 0.6$ $\mu \mathrm{m}^{2} /$ cell, $n=143$ and $11.7 \pm 0.5 \mu \mathrm{m}^{2} /$ cell, $n=142$ ), but was higher in insulin-injected fetuses (7.8 $\pm 0.8 \mu \mathrm{m}^{2} /$ cell, $\left.n=72\right)$ than in controls $\left(5.9 \pm 0.6 \mu \mathrm{m}^{2} /\right.$ cell, $\left.n=129, p<0.05\right)$ on day 21.5. Thus, glycogenolysis in type II cells appeared slowed down by insulin injections, which is consistent with the increased content of whole organ observed on day 21.5 (Table 1).

\section{DISCUSSION}

The present study shows that high levels of insulinemia in the rat fetus went along with reduced biosynthesis of lung surfactant in vivo. The effect, however, was small enough to be detectable

Table 1. Fetal body wt, lung wt, lung protein, and glycogen content in the different experimental groups on day 21.5 of gestation*

\begin{tabular}{|c|c|c|c|c|}
\hline & $\begin{array}{c}\text { Fetal body } \\
\text { wt } \\
\text { (g) }\end{array}$ & $\begin{array}{c}\text { Fetal lung } \\
\text { wet wt } \\
(\mathrm{mg})\end{array}$ & $\begin{array}{c}\text { Fetal lung proteins } \\
(\mu \mathrm{g} / \mathrm{mg} \mathrm{w} / \mathrm{v})\end{array}$ & $\begin{array}{l}\text { Fetal lung glycogen } \\
(\mu \mathrm{g} / \mathrm{mg} \mathrm{w} / \mathrm{v})\end{array}$ \\
\hline $\mathrm{NaCl}$-injected controls & $\begin{array}{c}4.30 \pm 0.04 \\
(75)\end{array}$ & $\begin{array}{c}112 \pm 4 \\
(34)\end{array}$ & $\begin{array}{c}102 \pm 3 \\
(18)\end{array}$ & $\begin{array}{c}15.1 \pm 0.8 \\
(18)\end{array}$ \\
\hline Insulin injections & $\begin{array}{c}4.60 \pm 0.06 \dagger \\
(70)\end{array}$ & $\begin{array}{c}129 \pm 5 \ddagger \\
(31)\end{array}$ & $\begin{array}{c}110 \pm 4 \\
(17)\end{array}$ & $\begin{array}{c}18.5 \pm 1.0 \ddagger \\
(17)\end{array}$ \\
\hline
\end{tabular}

\footnotetext{
* Mean \pm SEM of the number of individuals indicated in parentheses. The data represent the mean of eight to 10 litters for body and lung weight determinations and of five litters for lung protein and glycogen measurements. For these latter data three to four fetuses were used from each litter.

$\dagger$ Significant difference from saline-injected controls for $p<0.001$.

$\$$ Significant difference from saline-injected controls for $p<0.05$.

$\S$ Significant difference from fetuses from water-infused control rats for $p<0.01$.
} 
Table 2. Phospholipid composition of $S$ fraction, $R$ fraction, and whole lung ( $S+R$ fractions) in insulin-injected fetuses and their saline-injected controls (nmol Pi/mg wet tissue)*

\begin{tabular}{|c|c|c|c|c|c|c|c|c|}
\hline & Total phospholipids & $\mathrm{PC}$ & DSPC & $\mathrm{PE}$ & PI & PG & Triglycerides & Diglycerides \\
\hline \multicolumn{9}{|l|}{$S$ fraction } \\
\hline Controls & $6.8 \pm 0.2$ & $4.8 \pm 0.2$ & $3.3 \pm 0.1$ & $0.44 \pm 0.02$ & $0.19 \pm 0.02$ & $0.35 \pm 0.02$ & & \\
\hline Insulin & $5.8 \pm 0.3 \dagger$ & $3.6 \pm 0.1 \ddagger$ & $2.8 \pm 0.1 \S$ & $0.27 \pm 0.02 \ddagger$ & $0.15 \pm 0.01$ & $0.32 \pm 0.02$ & & \\
\hline \multicolumn{9}{|l|}{$\mathbf{R}$ fraction } \\
\hline Controls & $10.0 \pm 0.7$ & $4.7 \pm 0.25$ & $2.2 \pm 0.2$ & $2.25 \pm 0.20$ & $0.31 \pm 0.07$ & $0.29 \pm 0.08$ & & \\
\hline Insulin & $11.1 \pm 0.7$ & $5.2 \pm 0.3$ & $2.4 \pm 0.2$ & $2.20 \pm 0.15$ & $0.32 \pm 0.03$ & $0.22 \pm 0.02$ & & \\
\hline \multicolumn{9}{|c|}{ Total $(S+R)$} \\
\hline Controls & $16.8 \pm 0.4$ & $9.5 \pm 0.2$ & $5.5 \pm 0.3$ & $2.7 \pm 0.2$ & $0.50 \pm 0.04$ & $0.64 \pm 0.05$ & $3.3 \pm 0.05$ & $0.92 \pm 0.07$ \\
\hline Insulin & $16.9 \pm 0.7$ & $8.8 \pm 0.4$ & $5.2 \pm 0.3$ & $2.6 \pm 0.2$ & $0.47 \pm 0.04$ & $0.54 \pm 0.01$ & $2.8 \pm 0.3$ & $0.96 \pm 0.14$ \\
\hline
\end{tabular}

* Triglyceride and diglyceride content of whole lung ( $\mu \mathrm{g} / \mathrm{mg}$ wet tissue). Mean \pm SEM; $n=15$ for controls and 12 for insulin injected fetuses (five litters of controls and four litters of insulin-injected fetuses, three fetuses per litter).

$\dagger$ Significant difference from controls for $p<0.05$.

$\ddagger$ Significant difference from controls for $p<0.001$.

$\S$ Significant difference from controls for $p<0.025$.

Table 3. Phospholipid composition of $S$ fraction, $R$ fraction, and whole lung $(S+R$ fractions) in fetuses of glucose-infused or control water-infused rats (nmol Pi/mg tissue)*

\begin{tabular}{|c|c|c|c|c|c|c|c|c|}
\hline & Total phospholipids & $\mathrm{PC}$ & DSPC & PE & PI & PG & Triglycerides & Diglycerides \\
\hline \multicolumn{9}{|l|}{$S$ fraction } \\
\hline Controls & $8.65 \pm 0.50$ & $5.7 \pm 0.4$ & $4.3 \pm 0.3$ & $0.60 \pm 0.04$ & $0.23 \pm 0.04$ & $0.40 \pm 0.04$ & & \\
\hline Glucose infused & $7.20 \pm 0.45 \dagger$ & $4.30 \pm 0.25 \dagger$ & $3.4 \pm 0.2 \dagger$ & $0.50 \pm 0.03$ & $0.23 \pm 0.02$ & $0.24 \pm 0.03 \ddagger$ & & \\
\hline \multicolumn{9}{|l|}{$\mathrm{R}$ fraction } \\
\hline Controls & $8.75 \pm 0.40$ & $3.8 \pm 0.2$ & $2.35 \pm 0.20$ & $1.6 \pm 0.1$ & $0.11 \pm 0.01$ & $0.17 \pm 0.01$ & & \\
\hline Glucose infused & $9.2 \pm 0.3$ & $4.7 \pm 0.3 \dagger$ & $2.2 \pm 0.2$ & $2.2 \pm 0.1 \ddagger$ & $0.19 \pm 0.04$ & $0.11 \pm 0.01 \ddagger$ & & \\
\hline \multicolumn{9}{|l|}{ Total $(S+R)$} \\
\hline Controls & $17.4 \pm 0.9$ & $9.5 \pm 0.6$ & $6.65 \pm 0.40$ & $2.2 \pm 0.1$ & $0.34 \pm 0.03$ & $0.57 \pm 0.06$ & $1.7 \pm 0.2$ & $0.54 \pm 0.12$ \\
\hline Glucose infused & $16.4 \pm 0.5$ & $9.0 \pm 0.3$ & $5.6 \pm 0.3 \dagger$ & $2.7 \pm 0.2 \dagger$ & $0.42 \pm 0.04$ & $0.35 \pm 0.04 \ddagger$ & $2.3 \pm 0.3$ & $0.36 \pm 0.09$ \\
\hline
\end{tabular}

* Triglyceride content of whole lung ( $\mu \mathrm{g} / \mathrm{mg}$ wet tissue); mean $\pm \mathrm{SEM}, n=10$ for both groups; (four different litters).

$\dagger$ Significant difference from controls for $p<0.05$.

$\ddagger$ Significant difference from controls for $p<0.01$.

Table 4. Phospholipid composition of material recovered by lung lavage in cesarean newborns (percentage of total phospholipids)*

\begin{tabular}{lccccc}
\hline & PC & DSPC & PE & PI & PG \\
\hline Saline-injected controls (5) & $78.1 \pm 1.7$ & $50.8 \pm 1.2$ & $0.8 \pm 0.2$ & $2.7 \pm 0.6$ & $7.8 \pm 0.6$ \\
Insulin-injected newborns (6) & $76.1 \pm 2.3$ & $50.9 \pm 0.7$ & $0.8 \pm 0.3$ & $2.8 \pm 0.2$ & $5.9 \pm 0.2$ \\
Water-infused controls (7) & $76.4 \pm 1.8$ & $56.1 \pm 2.2$ & $0.8 \pm 0.1$ & $1.4 \pm 0.1$ & $4.7 \pm 0.3$ \\
Glucose infusion (8) & $73.8 \pm 1.5$ & $52.3 \pm 1.3$ & $0.9 \pm 0.2$ & $2.2 \pm 0.5$ & $5.5 \pm 0.3$ \\
\hline
\end{tabular}

* Mean \pm SEM of the number of determinations (litters) indicated in parentheses; no differences were significant.

only at the level of very specific parameters, i.e. the amount of isolated surfactant fraction and the lamellar body content of type II pneumocytes, but not at the level of whole lung phospholipid composition. This could explain why previous in vivo studies $(6$, 8 ) involving only whole tissue analysis failed to demonstrate any delaying effect of chronic "pure" hyperinsulinemia.

Comparing the effects of repeated insulin injections with those of glucose infusion, it appears that changes in PC and DSPC were quite similar, although a little more marked in fetuses from glucose-infused rats, since the reduction of DSPC was detectable at the level of whole lung in this latter model only. These changes would therefore appear as proper effects of excessive insulin, since they occurred in the presence of either hypoglycemia or hyperglycemia. The more marked changes seen after glucose infusion could be due to some synergistic effect of elevated glucose, and/or to the fact that repeated injections to the fetus and sustained hypoglycemia were sources of stress which could have counteracted insulin action in the first model. Indeed, hormones secreted under stress, such as corticosteroids or catecholamines, are well known for accelerating lung maturation (30). Therefore insulin effects could have been underestimated in insulin-injected fetuses.

A delaying effect of insulin on the increase of fetal lung PC in vivo is consistent with the repeatedly evidenced effects of insulin in in vitro systems (reviewed in Ref. 2). Regarding the possible underlying mechanism, recent data gained from in vitro approach suggest that insulin could act at the level of lung fibroblasts by inhibiting production of the fibroblast pneumonocyte factor, which in turn leads to understimulated surfactant production by epithelial type II cells (31). Some impairment in glycogen utilization could also play a role $(15,19)$.

Contrary to changes in PC, decreased PG and increased PI concentrations were seen after glucose infusion, but not after insulin injections. These changes can therefore be ascribed to 

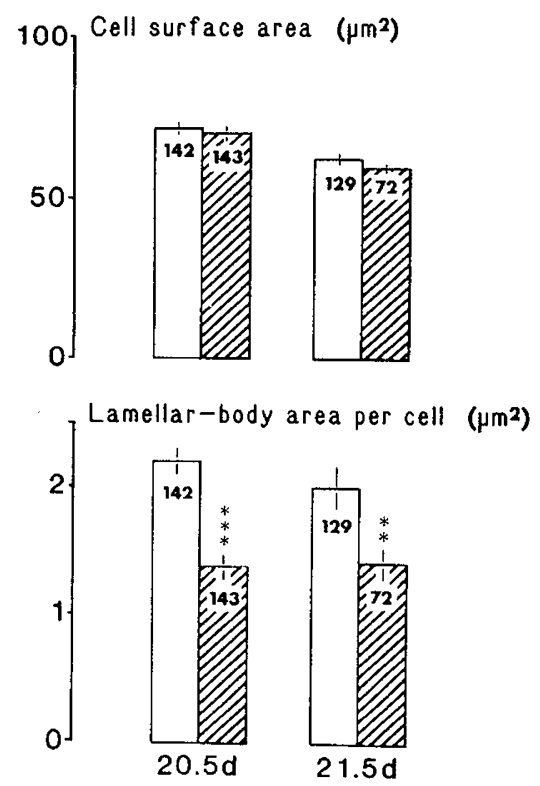

Fig. 2. Morphometric study of type II pneumocytes observed by electron microscopy. Top, surface area of cell profiles; bottom, total lamellar body area per cell profile; open bars, saline-injected controls; hatched bars, insulin-injected fetuses. Mean \pm SEM on the number of cell profiles which were examined as indicated in bars. ${ }^{* * *}$ Significant difference for $p<0.001 ;{ }^{* *}$ significant difference for $p<0.01$.

hyperglycemia rather than hyperinsulinemia, in keeping with previous investigations $(32,33)$ demonstrating that these alterations in PG-PI metabolism resulted from elevated blood myoinositol as a consequence of hyperglycemia. One can wonder about the physiological significance of these changes since phosphatidylglycerol-deficient surfactant has been shown to present normal surface tension properties, and PG-deficient adult rabbit have normal lung function (34). We previously found, however, that alveolar opening pressure was increased and blood oxygenation was decreased in PG-deficient newborn rats (33). Therefore, despite the data from adult animals, $\mathrm{PG}$ deficiency probably has a physiological meaning in the newborn, and the defect in PG resulting from maternal diabetes may have adverse consequences at birth.

It may appear surprising that changes seen in $\mathrm{S}$ fraction isolated from lung tissue were not reflected in composition of lung-lavage fluid. However, taking into account the fact that surfactant was reduced as a whole, since the major components and total phospholipids were decreased in similar proportions, it appears that changes in intraalveolar material, if present, were necessarily small and not detectable.

It should be emphasized that maternal glucose infusion which reproduced blood glucose and insulin levels similar to those observed in mild diabetes induced in rats by streptozotocin $(15$, 35 ), did not induce such marked effects on fetal lung maturation. In streptozotocin-induced diabetes, decreased amounts of PC, DSPC, and neutral lipids in whole lung, modified composition of lung lavage fluid, and impaired lung glycogenolysis were observed $(15,36)$. This suggests that abnormalities other than increases in blood glucose and insulin could be implicated in the delay of lung maturation associated with the diabetic pregnancy. A decrease of blood free corticosteroids (37) or of prostaglandin biosynthesis (38) could be involved. Placental alterations present in streptozotocin-induced diabetes (39), but not in chronic glucose infusion (14), might also have consequences on fetal nutrition and hormonal status which could account for differences between these models.

In conclusion, the present study provides insight into the role of fetal hyperinsulinemia in delaying lung maturation. It also indicates that hyperglycemia has proper effects in this process, which does not exclude a possible synergistic action with insulin. However, the results are in disagreement with the assumption $(8,40)$ that hyperglycemia rather than hyperinsulinemia is directly responsible for the deficiency of surfactant observed in infants of diabetic mothers. The likely involvement of other alterations in fetal "milieu interieur" suggests that the lung maturational delay results from a complex combination of events, not explainable by one single precipitating factor.

Acknowledgments. The authors are grateful to M. E. Dufour, G. Idriss, M. F. Kinebanyan, and C. Valenza for helpful technical assistance. The authors wish to thank Professor A. Jost and Professor L. Picon for providing the research facilities of their laboratories and they thank Professor P. M. Farrell for constructing advices and criticism.

\section{REFERENCES}

1. Robert MF, Neff RK, Hubbell JP, Taeusch HW, Avery ME 1976 Association between maternal diabetes and the respiratory-distress syndrome in the newborn. N Engl J Med 294:357-360

2. Bourbon JR, Farrell PM 1985 Fetal lung development in the diabetic pregnancy. Pediatr Res 19:253-267

3. Pedersen J, Bojsen-Møller B and Poulsen H 1954 Blood sugar in newborn infants of diabetic mother. Acta Endocrinol 15:33-52

4. Warburton D 1983 Chronic hyperglycemia with secondary hyperinsulinemia inhibits the maturational response of fetal lamb lungs to cortisol. J Clin Invest 72:433-440

5. Levine DH 1985 Hyperinsulinemia and decreased surfactant in fetal rabbits Dev Pharmacol Ther 8:284-291

6. Adamsons K, Mc Cormick KL, Susa JB, Widness JA, Singer DB, Schwartz R 1981 Effects of insulin on the biochemical and morphologic maturation of the fetus. J Perinatal Med 9(suppl 1):104-105

7. Patel DM, Rhodes PG 1984 Effects of insulin and hydrocortisone on lung tissue phosphatidylcholine and disaturated phosphatidylcholine in fetal rabbits in vivo. Diabetologia 27:478-481

8. Rooney SA, Chu AJ, Gross I, Marino PA, Schwartz R, Seghal P, Singer DB, Susa JB, Warshaw JB, Wilson CM 1983 Lung surfactant in the hyperinsulinemic fetal monkey. Lung 161:313-317

9. Bose CL, Manne DN, D'Ercole J, Lawson EE 1980 Delayed fetal pulmonary maturation in a rabbit model of diabetic pregnancy. J Clin Invest 66:220226

10. Sosenko IRS, Frantz III ID, Roberts RJ, Meyrick B 1980 Morphologic disturbance of lung maturation in fetuses of alloxan diabetic rabbits. Am Rev Respir Dis 122:687-696

11. Tydén O, Berne C, Ericksson U 1980 Lung maturation in fetuses of diabetic rats. Pediatr Res 14:1192-1195

12. Gewolb IH, Barrett C, Wilson CM, Warshaw JB 1982 Delay in pulmonary glycogen degradation in fetuses of streptozotocin diabetic rats. Pediatr Res $16: 869-873$

13. Pignol B, Bourbon J, Rieutort M 1983 Diminution du phosphatidylglycérol pulmonaire chez les foetus de rattes rendues diabétiques par la streptozotocine. Comptes Rendus Acad Sci (Paris) 297:339-342

14. Ktorza A, Girard JR, Kinebanyan MF, Picon L 1981 Hyperglycemia induced by glucose infusion in the unrestrained pregnant rat during the last three days of gestation: metabolic and hormonal changes in the mother and the fetuses. Diabetologia 21:541-545

15. Bourbon JR, Pignol B, Marin L, Rieutort M, Tordet C 1985 Maturation of fetal rat lung in diabetic pregnancies of graduated severity. Diabetes 34:734743

16. Frosolono MF, Charms BL, Pawlowski R, Slivka S 1970 Isolation, characterization, and surface chemistry of a surface-active fraction from dog lung. $\mathbf{J}$ Lipid Res 11:439-457

17. Sanders RL, Longmore WJ 1975 Phosphatidylglycerol in rat lung. II. Comparison of occurrence, composition and metabolism in surfactant and residual lung fractions. Biochemistry 14:835-840

18. Rieutort M, Farrell PM, Engle MJ, Pignol B, Bourbon JR 1986 Changes in surfactant phospholipids in fetal rat lungs from normal and diabetic pregnancies. Pediatr Res 20:650-654

19. Bourbon JR, Rieutort M, Engle MJ, Farrell PM 1982 Utilization of glycogen for phospholipid synthesis in fetal rat lung. Biochim Biophys Acta 712:382389

20. Kervran A, Rieutort M, Guillaume M 1976 A simultaneous radioimmunoassay for growth hormone and insulin in the plasma of rats and rabbits. Diabete Metab 2:67-72

21. Chan TM, Exton JM 1976 A rapid method for the determination of glycogen content and radioactivity in small quantities of tissue or isolated hepatocytes. Anal Biochem 71:96-105

22. Scharcterle GR, Pollack RL 1973 A simplified method for the quantitative assay of small amounts of protein in biological material. Anal Biochem 51:654-655

23. Folch J, Lees M, Sloan-Stanley GH 1957 A simple method for the isolation 
and purification of total lipids from animal tissues. J Biol Chem 236:497509

24. Mason JR, Nellenbogen J, Clements JA 1976 Isolation of disaturated phosphatidylcholine with osmium tetraoxide. J Lipid Res 17:281-284

25. Eggstein M, Kreutz FH 1966 A new determination of neutral fats in blood serum and tissue. I Principles, procedures and discussion of the method. Klin Wochenschr 44:262-267

26. Hirsch JG, Fedorko ME 1968 Ultrastructure of human leukocytes after simultaneous fixation with glutaraldehyde and osmium tetroxide and post fixation in uranyl acetate. J Cell Biol 38:615-627

27. Weibel ER, Kistler GS, Scherle WF 1966 Practical stereological methods for morphometric cytology. J Cell Biol 30:23-28

28. Picon L 1967 Effects of insulin on growth and biochemical composition of the rat fetus. Endocrinology 81:1419-1421

29. Bourbon JR, Farrell PM, Doucet E, Brown DJ, Valenza C Biochemical maturation of fetal rat lung. A comprehensive study including surfactant determination. Biol Neonate (in press)

30. Smith BT, Bogues WC 1980 Effects of drugs and hormones on lung maturation in experimental animal and man. Pharmacol Ther 9:51-74

31. Carlson KS, Smith BT, Post M 1984 Insulin acts on the fibroblast to inhibit glucocorticoid stimulation of lung maturation. J Appl Physiol 57:1577-1579

32. Hallman M, Epstein BL 1980 Role of myo-inositol in the synthesis of phosphatidylglycerol and phosphatidylinositol in the lung. Biochem Biophys Res
Commun 92:1151-1159

33. Bourbon JR, Doucet E, Rieutort M, Pignol B, Tordet C 1986 Role of myoinositol in impairment of phosphatidylglycerol biosynthesis in the diabetic pregnancy. Physiological consequences of a phosphatidylglycerol-deficient surfactant in the newborn rat. Exp Lung Res 11:195-207

34. Beppu OS, Clements JA, Goerke J 1983 Phosphatidylglycerol-deficient lung surfactant has normal properties. J Appl Physiol 55:496-502

35. Kervran A, Guillaume M, Jost A 1978 The endocrine pancreas of the fetus from diabetic pregnant rat. Diabetologia 15:387-393

36. Singh M, Feigelson M 1983 Effects of maternal diabetes on the development of carbohydrate metabolizing enzymes, glycogen deposition and surface active phospholipid levels in the fetal rat lung. Biol Neonate 43:33-42

37. Mulay S, Solomon S 1983 Influence of streptozotocin induced diabetes in pregnant rats on cytoplasmic glucocorticoid receptors in fetal tissues. $J$ Endocrinol 96:335-345

38. Tsai MY, Schallinger LE, Josephson MW, Brown DM 1982 Disturbance of pulmonary prostaglandin metabolism in fetuses of alloxan diabetic rabbits. Biochim Biophys Acta 712:395-399

39. Abramovici A, Sporn J, Prager R, Shaltiel A, Laron Z, Liban E 1978 Glycogen metabolism in the placenta of streptozotocin diabetic rats. Horm Metab Res 10:195-199

40. Tydén O, Ericksson UJ, Berne C 1986 Fetal lung maturation in diabetic pregnancy. Acta Endocrinol 112(suppl 277):101-106 